\title{
Justification of the choice of the type of forage harvester for farms
}

\author{
Aleksandr Golovkov ${ }^{1}$, Andrey Boiko ${ }^{2, *}$, and Mikhail Chaava ${ }^{2}$ \\ ${ }^{1}$ Central-chenozem state district machine testing station, Kurskiy region, Kurskiy district, Kamishi, \\ 305512, Russia \\ ${ }^{2}$ Don State Technical University, Gagarin Square, 1, Rostov-on-Don, 344000, Russia.
}

\begin{abstract}
The results of tests of feed-harvesting combines of domestic and foreign manufacturers for the last ten years are presented. Recommendations on the choice of the studied equipment are given.
\end{abstract}

\section{Introduction}

Forage production and crop production are the fundamental sectors of agriculture, which determine the state of the country's food security, as well as the state of animal husbandry and it have a significant impact on solving the problems of stabilization and biologization of agriculture, increasing soil fertility and environmental protection. In turn, the high yield of grain crops and the productivity of forage lands will require the use of high-performance forage and grain harvesting equipment and modern technologies of forage harvesting and storage. In agriculture of all countries, without exception, the process of updating agricultural equipment is taking place by creating more advanced designs or drawing on the experience of other countries' producers.

In the Kurskiy region farms from February 2018, There were 197 self-propelled forage harvesters, 45 were foreign, i.e. 152 combines were domestic, $80 \%$ are combine harvesters produced by Rostselmash Combine Plant . The share of imported (foreign) forage combines is $22.8 \%$; if two years ago the share of foreign combines was $22.2 \%$, then by February 2018 this value is already $29.8 \%$. All this to some extent, but especially the need to produce its own domestic and given the demand of agricultural producers, gave impetus to the design organization Rostselmash Combine Plant for the development of new high-performance fodder harvesting machines.

The aim of the research is to needful for using the main group of forage harvesters for agricultural producers in the Russian Federation.

\section{Materials and methods}

The studies were carried out according to the results of tests at the Central Chernozem State Zonal Machine Testing Station.

\footnotetext{
* Corresponding author: andreyboi@yandex.ru
} 


\section{Results and discussions}

The combines produced by the manufacturer Rostselmash can serve as an example for the fodder production industry: in addition to the serially produced and successfully proven DON 680M, this is the next line of self-propelled fodder harvesters: RSM 1401/1403, RSM F 2650 and RSM F 1300, and in the silo harvesting season of 2018, this enterprise plans to submit to the FGBU TsCh II for the qualification tests of a self-propelled forage harvester RSM F 2550 with an installed $400 \mathrm{~kW}$ (544 hp) imported engine. According to the constructional design, the fodder harvesters RSM 1401 and RSM 1403, including for export, do not have any fundamental differences. For small and medium-sized businesses, this manufacturer except DON 680M, equipped with a YaMZ-238DK-1 engine with a power of $213 \mathrm{~kW}$ or $290 \mathrm{hp}$ offers RSM F 1300 with a motor installation of domestic production YMZ-238 with a power of $243 \mathrm{~kW}$ or $330 \mathrm{hp}$ These forage harvesters are designed for cutting maize in any phase of ripeness of grain, sorghum, sunflower, other tall stem crops, mowing of seeded and natural grasses with simultaneous grinding and loading into vehicles.

Combines were submitted to the tests in the following configuration: self-propelled grinding unit on a wheel course; suitable harvesters for rough crops.

Self-propelled threshing units of these combines have no fundamental differences in design and include a feeder, threshing unit, an operator's workplace with a control platform, a chassis, a rethreshing unit, an accelerator of emission, a turning device, a silo line, hydraulic equipment, electrical equipment, a diesel engine, a sensor system metal detector and stone detector, centralized lubrication system (for RSM 1401/1403, RSM F 2650 - base, for RSM F 1300 - optional) and belt-mounted water. The main difference in the design of the reapers for harvesting coarse-grained crops is only in its width of capture, namely in the number of feed drums: DON 680M and RSM F 1300 - 4 combines .; RSM 1401 and RSM 1403 - 4 combines and RSM F 2650 - 6 combines.

We present the results in the form of table 1 of the laboratory-field tests for RSM F 2650 in the phase of harvesting corn for silage with both the included and the disconnected pre-grains of grain and at different cutting lengths. Laboratory field tests of a self-propelled RSM F 2650 forage harvester in a Kemper - 475 plus harvester unit were carried out on harvesting corn $70 \mathrm{~cm}$ wide with simultaneous additional grain reduction and without regrinding of grain with silo loading into a vehicle.

Thus, the test conditions for the self-propelled RSM F 2650 forage harvester and Kemper - 475 plus harvester for harvesting coarse crops of $7.5 \mathrm{~m}$ with a working width of $7.5 \mathrm{~m}$ were typical for this type of work and did not hinder the sustainable process of harvesting corn for silage in the stage of ripeness.

Weather conditions, soil conditions and characteristics of the crop to be harvested for the testing period did not interfere with the stable flow of the process. In general, the test conditions were typical for this year and type of work.

The tests were carried out without crusher unit of a grain and crusher unit for three installed cutting lengths: 20;10 and $4 \mathrm{~mm}$. Experiments were carried out at the cutting length of $10 \mathrm{~mm}$ in the mode of nominal productivity and in the optimal mode for operational and technological evaluation.

The working speed of the harvesting unit was determined naturally by the installation cutting length and the high-quality execution of the technological process. The installation cutting height and the actual width of the header in all variants of experiments was $25 \mathrm{~cm}$ and $7.0 \mathrm{~m}$, respectively. Productivity and throughput ability in work of RSM F 2650 without a crusher unit on all cutting lengths obtained is higher than when the combine works with crusher unit . 
Total losses (with a cutting length: $20 \mathrm{~mm} ; 10 \mathrm{~mm}$ - nominal capacity; $10 \mathrm{~mm}$ operating mode and $4 \mathrm{~mm}$ ) in all modes were obtained within the Normative requirements (no more than $1 \%$ ) and amounted to:

- $0.80 ; 0.78 ; 0,80$ and $0,71 \%$ - without grain crusher unit.;

$-0.71 ; 0.70 ; 0,73$ and $0,71 \%$ - with grain crusher unit.

The completeness of the harvest in this case was in the range of respectively $99.20 \ldots$ $99.29 \%$ and $99.27 \ldots 99.30 \%$, which satisfied the permissible ND value - not less than $99.0 \%$.

The throughput ability at the set cutting lengths were:

- 72,8; 60,$8 ; 51,9$ и 34,2 кг/с - without grain crusher unit.;

- 59,8;49,3; 42,6 и 29,1 кг/с - with grain crusher unit.

The quality of grinding plant material (particles up to $30 \mathrm{~mm}$ ) along the established cutting lengths was obtained in the range from 91.0 to $96.0 \%$, which was at the level of the Normative requirements - not less than $85 \%$. At the level of the specification (at least $22 \mathrm{~m}$ ) in all cutting modes, the product's emission range was also obtained.

In the laboratory field tests it was found that the self-propelled forage harvester RSM F 2650 with the header Kemper - 475 characterized by high throughput ability and performance; the stability of the technological process of harvesting corn in the wax ripeness phase, with or without a grain grinder, and at the same time ensuring high quality of the ground product. All indicators of the quality of the process performance combine RSM F 2650 meet the requirements of Normative. The throughput ability for cutting of corn in the phase of wax ripeness of grain with a cutting length of $10 \mathrm{~mm}$ and the work of a combine with a pre-grinder produced $42.6 \mathrm{~kg} / \mathrm{s}$. With an installation cut height of $25 \mathrm{~cm}$, the actual cut height was $23.4 \mathrm{~cm}$. The amount (mass) of the crushed product (particles up to $30 \mathrm{~mm}$ ) of its total crushed mass with an installation cut length of $10 \mathrm{~mm}$ was $96 \%$, which met the Normative value - no less than $85 \%$. The splitting of the stems obtained $100 \%$, which also met the requirements of ND - $100 \%$. The degree of destruction of waxy maize grains was equal to $100 \%$ (according to Normative - not less than $99 \%$ ). Completeness of the harvest amounted to $99.27 \%$ with an acceptable value for Normative not less than $99 \%$.

The obtained operational and technological indicators show that the RSM F 2650 forage harvester with a power installation of $650 \mathrm{hp} \mathrm{Kemper-475}$ plus in a complete set with a corn header for harvesting corn is a promising machine that fits into the agrotechnology of a high-performance method of harvesting corn for silage and will find application in large livestock Agrofirms or Agroholdings.

Table 1. Laboratory field tests RSM F 2650

\begin{tabular}{|c|c|c|c|c|c|c|c|c|c|}
\hline \multirow{3}{*}{ Indicator } & \multicolumn{9}{|c|}{ The value of the indicator: } \\
\hline & \multirow{2}{*}{$\begin{array}{l}\text { Normati } \\
\text { ve }\end{array}$} & \multicolumn{8}{|c|}{ Test data } \\
\hline & & \multicolumn{4}{|c|}{$\begin{array}{l}\text { without grain crusher } \\
\text { unit }\end{array}$} & \multicolumn{4}{|c|}{ with grain crusher unit } \\
\hline 1 & 2 & 3 & 4 & 5 & 6 & 7 & 8 & 9 & 10 \\
\hline Cutting length, $\mathrm{mm}$ & $\begin{array}{l}\text { from } 4 \\
\text { to } 22\end{array}$ & 20 & $10^{*}$ & $\begin{array}{l}10^{*} \\
*\end{array}$ & 4 & 20 & $10^{*}$ & $\begin{array}{l}10^{*} \\
*\end{array}$ & 4 \\
\hline $\begin{array}{l}\text { The speed of the unit, km / } \\
\text { h }\end{array}$ & $\begin{array}{l}\text { No more } \\
15\end{array}$ & 9,8 & 8,8 & 7,5 & 5,0 & 7,8 & 6,7 & 5,8 & 4,0 \\
\hline Capacity, kg / s & No data & 72,8 & 60,8 & 51,9 & 34,2 & 59,8 & 49,3 & 42,6 & 29,1 \\
\hline
\end{tabular}




\begin{tabular}{|c|c|c|c|c|c|c|c|c|c|}
\hline 1 & 2 & 3 & 4 & 5 & 6 & 7 & 8 & 9 & 10 \\
\hline $\begin{array}{l}\text { Productivity in } 1 \text { hour of } \\
\text { basic time with a cutting } \\
\text { length of at least } 22 \mathrm{~mm}, \mathrm{t} \text { / } \\
\mathrm{h} \text {, } \\
\text { in phase } \\
\text { - milky or milky wax } \\
\text { ripeness } \\
\text { - wax or full ripeness }\end{array}$ & $\begin{array}{l}\text { not } \\
\text { less: } \\
200 \\
90\end{array}$ & $\begin{array}{c}254 \\
1\end{array}$ & $\begin{array}{c}219 \\
1\end{array}$ & $\begin{array}{c}189 \\
3\end{array}$ & $\begin{array}{c}124, \\
2\end{array}$ & $\begin{array}{c}213 \\
0\end{array}$ & $\begin{array}{c}176 \\
3\end{array}$ & $\begin{array}{c}153 \\
3\end{array}$ & $\begin{array}{c}105, \\
0\end{array}$ \\
\hline $\begin{array}{l}\text { Cutting height, } \mathrm{mm}: \\
\text { - installation } \\
\text { - actual }\end{array}$ & $\begin{array}{c}\text { No more } \\
10 \\
-\end{array}$ & $\begin{array}{c}25 \\
23,5\end{array}$ & $\begin{array}{c}25 \\
23,5\end{array}$ & $\begin{array}{c}25 \\
23,6\end{array}$ & $\begin{array}{c}25 \\
23,3\end{array}$ & $\begin{array}{c}25 \\
23,4\end{array}$ & $\begin{array}{c}25 \\
23,4\end{array}$ & $\begin{array}{c}25 \\
23,4\end{array}$ & $\begin{array}{c}25 \\
23,4\end{array}$ \\
\hline Total losses, $\%$, including: & $\begin{array}{c}\text { No more } \\
1\end{array}$ & 0,80 & 0,78 & 0,80 & 0,71 & 0,71 & 0,70 & 0,73 & 0,71 \\
\hline - cut plants & No data & \multicolumn{8}{|c|}{ absent } \\
\hline - uncut plants & same & \multicolumn{8}{|c|}{ absent } \\
\hline - from high cut & $-\ll-$ & \multicolumn{8}{|c|}{ absent } \\
\hline - ground mass & $\begin{array}{l}-\ll- \\
\end{array}$ & \multicolumn{8}{|c|}{ absent } \\
\hline $\begin{array}{l}\text { - leaves, cobs and their } \\
\text { parts }\end{array}$ & $-\ll-$ & 0,80 & 0,78 & 0,80 & 0,71 & 0,71 & 0,70 & 0,73 & 0,71 \\
\hline Completeness of harvest $\%$ & $\begin{array}{c}\text { not } \\
\text { less } 99\end{array}$ & 99,2 & 99,2 & 99,2 & 99,3 & 99,3 & 99,3 & 99,3 & 99,3 \\
\hline $\begin{array}{l}\text { Grinding quality: } \\
\text { - fractional composition of } \\
\text { corn according to the } \\
\text { established cutting } \\
\text { length, } \% \text {, particle size, } \\
\text { mm: } \\
\text { from } 0 \text { to } 10.0 \\
\text { from } 10.1 \text { to } 20.0 \\
\text { from } 20.1 \text { to } 30.0 \\
\text { from } 30.1 \text { to } 50.0 \\
\text { from } 50.1 \text { to } 120.0 \\
\text { over } 120\end{array}$ & $\begin{array}{c}\text { No data } \\
\text { same } \\
-\ll- \\
-\ll- \\
-\ll- \\
-\ll-\end{array}$ & $\begin{array}{c}60,0 \\
22,0 \\
13,0 \\
2,0 \\
2,8 \\
0,2\end{array}$ & $\begin{array}{c}61,0 \\
23,0 \\
9,0 \\
3,0 \\
3,6 \\
0,4\end{array}$ & $\begin{array}{c}58,0 \\
23,0 \\
14,0 \\
2,0 \\
2,6 \\
0,4\end{array}$ & $\begin{array}{c}48,0 \\
25,0 \\
18,0 \\
3,0 \\
5,0 \\
1,0\end{array}$ & $\begin{array}{c}78,0 \\
16,0 \\
3,0 \\
1,0 \\
2,0 \\
0,0\end{array}$ & $\begin{array}{c}76,0 \\
17,0 \\
4,0 \\
1,0 \\
1,5 \\
0,5\end{array}$ & $\begin{array}{c}75,0 \\
16,0 \\
5,0 \\
1,5 \\
2,0 \\
0,5\end{array}$ & $\begin{array}{l}63,0 \\
21,0 \\
10,0 \\
2,0 \\
3,5 \\
0,5\end{array}$ \\
\hline $\begin{array}{l}\text { Quality grinding plant } \\
\text { product (particles up to } 30 \\
\text { mm), } \%\end{array}$ & $\begin{array}{l}\text { No more } \\
85\end{array}$ & 95,0 & 95,0 & 93,0 & 91,0 & 96,0 & 96,0 & 94,0 & 92,0 \\
\hline $\begin{array}{l}\text { Weighted average particle } \\
\text { size, } \mathrm{mm}\end{array}$ & No data & 16,9 & 13,3 & 13,2 & 12,8 & 12,9 & 11,1 & 10,1 & 9,6 \\
\hline Standard deviation, $\mathrm{mm}$ & No data & 19,7 & 15,5 & 16,6 & 15,4 & 16,7 & 12,7 & 14,2 & 12,2 \\
\hline Splitting of stalks, $\%$ & 100 & 100 & 100 & 100 & 100 & 100 & 100 & 100 & 100 \\
\hline $\begin{array}{l}\text { The degree of destruction } \\
\text { of corn kernels in the phase } \\
\text { of wax ripeness, } \%\end{array}$ & $\begin{array}{l}\text { No more } \\
99\end{array}$ & 99,9 & 100 & 99,9 & 100 & 100 & 100 & 100 & 100 \\
\hline Cutting ejection range, $\mathrm{m}$ & $\begin{array}{l}\text { No more } \\
22\end{array}$ & 29,8 & 29,6 & 28,5 & 28,2 & 29,1 & 28,8 & 28,7 & 28,4 \\
\hline
\end{tabular}




\section{Conclusions}

Based on the results of these tests, it can be concluded that the RSM F 2650 forage harvester with the rotary harvester Maize Header 750 and Kemper-475 plus for the harvesting of corn and high-stem crops "Maize Header 750" consistently performs the process and for all technological indicators and indicators of quality of work meets the requirements of ND. The two-year experience of testing RSM F 2650 showed that its use in specialized livestock farms in our and other areas of the station's activity in normal organization of harvesting corn for silage, i.e., when at least 5-6 heavy vehicles are assigned to it when silage is transported it is quite possible in $1-2$ days to "fill" the silo pit.

Domestic fodder harvesters are also equipped with an automatic sharpening system for the knives of the chopping apparatus and supplying the shearing bar, installing a hydraulic drive to smoothly change the length of the cut, having a centralized lubrication system, targeting the silo to the vehicle body, and the ability to add preservatives during the cleaning process sufficient for a full day of fuel capacity tank, automatic copy of the field relief and much more.

It should be recognized that in terms of reliability, we are lagging behind foreign countries, but we also need to consider the cost of equipment, and they, like other types of resources, should pay off with technological results - field and farm productivity. In Russia, their productivity due to natural conditions is obviously lower, since in Western countries the growing season is twice as large as in the middle zone, and the biological yield is directly related to its duration, since plants absorb $1 \%$ of solar energy regardless of geographic placement of production.

If, however, foreign equipment is purchased, it is necessary first of all to take into account the development prospects of the domestic agro-industrial complex and the results of state tests in comparison with the indicators of the Russian counterpart in comparable conditions, as well as the energy consumption and first of all the cost of this equipment.

\section{References}

1. Fedorenko VF / Cleaning and post-harvest treatment of grass seed M., FGNU "Rosinformagrote", 2003. - p. 4.

2. Lachuga Yu.F. / On the scientific support of the engineering and technical system in the agroindustrial complex / Journal "Agricultural Machinery and Technologies", No. 3, 2010. - P. 3-10.

3. Zherdev MN. Golovkov AN / Scientific and analytical review of the results of tests of forage harvesting equipment. Part 2 / Central Chernozemna IIA, 2016. - C 4; 57 - 78; 101 103.

4. Izmailov A.Yu., Moskovsky M.N., Podlesnyi D.S. Consumer Harness, International Conference on Modern and International Trade Units, International Conference on Modern and International Trade Units (ICMTMTE 2018) electronic edition. Ser. "MATEC Web of Conferences" 2018. p. 05010.

5. Zhalnin E.V., Cench Yu.S., Pyanov V.S. Technique for functional and technical parameters of agricultural machinery and technologies. 2018. V. 12. No. 2. p. 4-8. 